\title{
A new threat to local marine biodiversity: filamentous mats proliferating at mesophotic depths off Rapa Nui
}

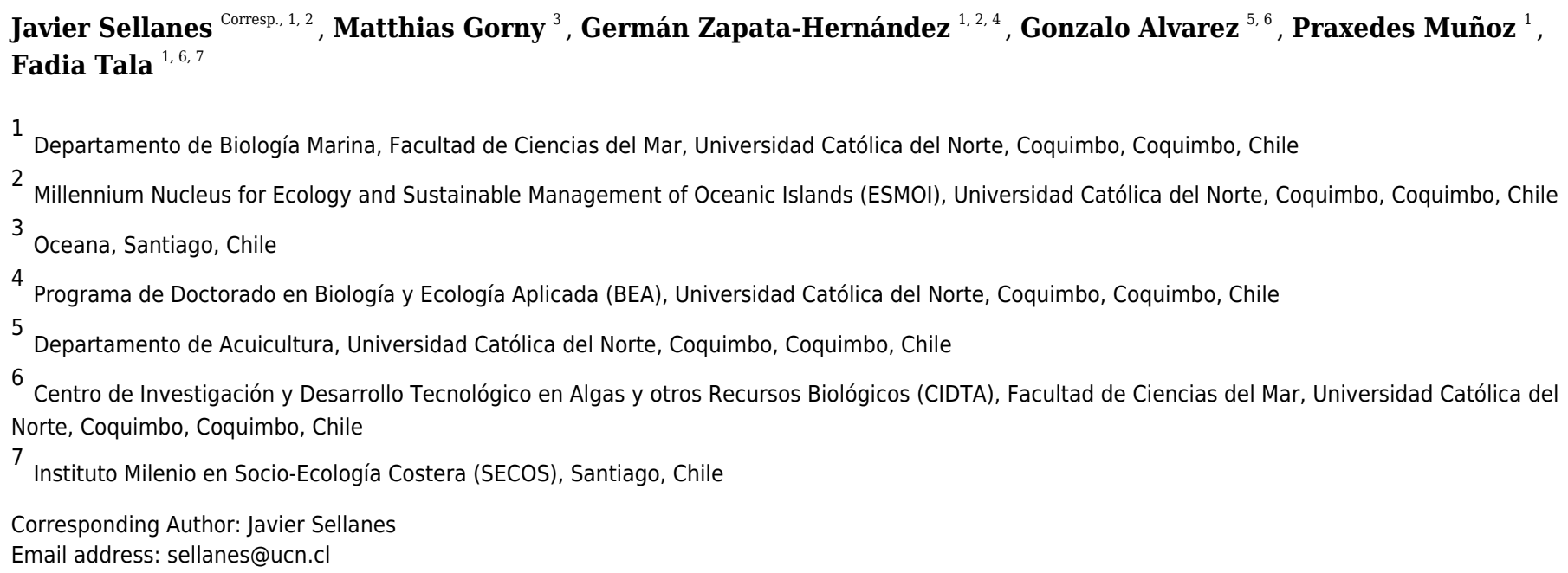

Mesophotic and deeper habitats ( 40 to $350 \mathrm{~m}$ in depth) around Rapa Nui (Easter Island) were investigated using a remotely operated vehicle. We observed extensive fields of filamentous cyanobacteria-like mats covering sandy substrates and mostly dead mesophotic Leptoseris spp. reefs. These mats covered up to $100 \%$ of the seafloor off Hanga Roa, the main village on the island, located on its western side. The highest mortality of corals was observed at depths between 70 and $95 \mathrm{~m}$ in this area. Healthy Leptoseris reefs were documented off the northern and southeastern sides of the island, which are also the least populated. A preliminary morphologic analysis of samples of the mats indicated that the assemblage is composed of at least four filamentous taxa, including two cyanobacteria (cf. Lyngbya sp. and Pseudoanabaena sp.), a brown alga (Ectocarpus sp.), and a green alga (Cladophora sp.). An ongoing eutrophication process is suggested as a potential driver of the proliferation of these filamentous mats off Hanga Roa village 


\section{A new threat to local marine biodiversity: filamentous 2 mats proliferating at mesophotic depths off Rapa Nui}

4 Javier Sellanes ${ }^{1,2 *}$, Matthias Gorny ${ }^{3}$, Germán Zapata-Hernández ${ }^{1,2,4}$, Gonzalo Álvarez ${ }^{5,6}$, Práxedes

5 Muñoz $^{1} \&$ Fadia Tala ${ }^{1,6,7}$

6

7 1Departamento de Biología Marina, Facultad de Ciencias del Mar, Universidad Católica del Norte,

8 Coquimbo, Chile.

$9{ }^{2}$ Millennium Nucleus for Ecology and Sustainable Management of Oceanic Islands (ESMOI),

10 Universidad Católica del Norte, Coquimbo, Chile.

$11{ }^{3}$ Oceana Chile.

12 4Programa de Doctorado en Biología y Ecología Aplicada (BEA), Universidad Católica del Norte, 13 Coquimbo, Chile.

$14{ }^{5}$ Departamento de Acuicultura, Facultad de Ciencias del Mar, Universidad Católica del Norte, 15 Coquimbo, Chile.

$16{ }^{6}$ Centro de Investigación y Desarrollo Tecnológico en Algas y otros Recursos Biológicos 17 (CIDTA), Facultad de Ciencias del Mar, Universidad Católica del Norte, Coquimbo, Chile.

$18{ }^{7}$ Instituto Milenio en Socio-Ecología Costera (SECOS), Santiago, Chile

$20 *$ Corresponding author:

21 Javier Sellanes ${ }^{1,2}$

22 Email address: sellanes@ucn.cl 


\section{Abstract}

24 Mesophotic and deeper habitats ( 40 to $350 \mathrm{~m}$ in depth) around Rapa Nui (Easter Island) were investigated using a remotely operated vehicle. We observed extensive fields of filamentous cyanobacteria-like mats covering sandy substrates and mostly dead mesophotic Leptoseris spp. reefs. These mats covered up to $100 \%$ of the seafloor off Hanga Roa, the main village on the island, located on its western side. The highest mortality of corals was observed at depths between 70 and $95 \mathrm{~m}$ in this area. Healthy Leptoseris reefs were documented off the northern and southeastern sides of the island, which are also the least populated. A preliminary morphologic analysis of samples of the mats indicated that the assemblage is composed of at least four filamentous taxa, including two cyanobacteria (cf. Lyngbya sp. and Pseudoanabaena sp.), a brown alga (Ectocarpus sp.), and a green alga (Cladophora sp.). An ongoing eutrophication process is suggested as a potential driver of the proliferation of these filamentous mats off Hanga Roa village.

\section{Introduction}

Mesophotic coral ecosystems are deep reef communities that typically occur at a depth range of 30 or 40 to over $150 \mathrm{~m}$ (Baker et al., 2016). They are formed mainly by coral taxa adapted to living in low-light conditions and often also include other structure-forming taxa, such as sponge and macroalgae species (Baker et al., 2016; Slattery \& Lesser, 2021). These ecosystems are now recognized as ecologically distinct and independent from their shallower counterparts and contain a substantial diversity of unique biota that is still unexplored in most parts of the world (Rocha et al., 2018). The lack of knowledge about these deep coral ecosystems is a consequence of the difficulty of accessing the depths at which they occur, as technical diving (e.g., rebreather diving using trimix) or sophisticated submarine equipment (e.g., remotely operated vehicles, autonomous 
46 drop-cams, or manned submersibles) are required to carry out research. Mesophotic coral 47 ecosystems are vulnerable to a series of anthropogenic stressors, such as fishing, thermal stress, 48 diseases, pollution, invasive species, the marine aquarium trade, oil and gas exploration, cables, 49 and pipelines (Andradi-Brown et al., 2016). Rapa Nui (Easter Island; $27^{\circ} 07^{\prime} \mathrm{S}, 109^{\circ} 22^{\prime} \mathrm{W}$ ), which formed $\sim 0.8 \mathrm{Mya}$, is a remote island located at the westernmost end of the large chain of seamounts comprising the Salas y Gómez ridge, relatively close to the East Pacific Rise (Rodrigo, Díaz \& González-Fernández, 2014). Located in the easternmost apex of the Polynesian triangle, it is recognized for the high overall endemism

levels of its coastal marine fishes ( 22\%; Randal \& Cea, 2010) and invertebrate taxa (4\% to $34 \%$; see Fernández et al., 2014). However, this unique marine biodiversity is severely threatened by several anthropogenic impacts, including overfishing (Zylich et al., 2014), plastic pollution (Hidalgo-Ruz et al., 2021), exacerbated tourism (Figueroa \& Rotarou, 2016), coastal erosion and terrestrial runoff (Mieth \& Bork, 2005), and potential pollution from the percolation of domestic sewage and landfill contaminants into aquifers (Rosa, 2013).

Recently (2015-2018), through the use of a remotely operated vehicle (ROV), we have been able to access unexplored marine habitats (from $\sim 40$ to $350 \mathrm{~m}$ deep) around the island, as well as at nearby seamounts, allowing for a first assessment of the biodiversity of mesophotic ecosystems and deeper sites (Easton et al., 2019), generation of new records of fauna, including fishes (e.g., Easton et al., 2017) and echinoderms (Mecho et al., 2019), and reports of vast fields of the solitary mesophotic mushroom coral Cycloseris vaughani (Hoeksema, Sellanes \& Easton, 2019). In these surveys, a chance discovery was the presence of dense and extensive fields of filamentous mats, covering the seafloor and nearby reefs at mesophotic depths at several locations around the island. It is known that cyanobacteria are a common constituent of coral reef ecosystems (Stal, 2000) and 
69 play an important role in nitrogen fixation and primary production (Charpy et al., 2012). However,

70 under certain conditions, they can undergo massive proliferation, affecting the health of the

71 ecosystem (Bakker et al., 2017; Ford et al., 2017). These events have been associated with variation

72 in irradiance, nutrient supply, and other natural and anthropogenic disturbances (Ford et al., 2018).

73 These proliferation events seem to be increasing at a global scale because of alterations in local

74 biogeochemical cycles related to climate change (Paul, 2008; Paerl \& Paul, 2012). These

75 filamentous mats could develop into such dense blooms that they could even wash ashore,

76 producing a mass accumulation, as reported by Nagle and Paul (1999) for Guam. At this location,

77 benthic marine cyanobacterial blooms often occur in the presence of diverse assemblages of

herbivorous fishes and urchins, but the underlying factors causing these proliferations, as well as

the interaction mechanisms between grazers and these mats (since cyanobacteria are known to produce feeding-deterrent compounds), are still poorly understood (Cissell, Manning \& McCoy, 2019; Ford et al., 2021). In addition, cyanobacteria have been directly linked with ciguatera fish poisoning outbreaks (Laurent et al., 2008), and mats can create suitable habitats for other toxic microalgae, including toxin-producing dinoflagellates, thus generating co-occurring blooms (Paerl

84 \& Otten, 2013). Although several microalgae species are not toxic, their growth could produce low oxygen conditions as a consequence of organic matter accumulation and associated degradation processes in the bottom water, thus affecting the benthic communities (Albert et al.,

87 2012). It is also possible that the rise of fixed nitrogen may modify its budget in the system,

88 promoting the growth of macroalgae, further increasing the organic matter content within the sediments, and decreasing porewater oxygen content (Brocke et al., 2015; 2018). In some environments, mats form associations with sulfate-reducing bacteria, producing sulfide, which is 
91 toxic for corals and establishes black band disease (Myers \& Richardson, 2009; Charpy et al., 92 2012).

93 It has also been reported that in littoral reefs, green algae (chlorophytes) are common indicators of 94 eutrophication (Barile, 2004). Most of the species in this group proliferate due to increased nutrient 95 inputs, tolerate a wide range of environmental conditions, aggressively compete against sensitive 96 corals, and have sub-lethal effects on several of the biological functions of corals (Koop et al., 97 2001; Fabricius, 2005; Birrel et al., 2008).

98 In this context, the aims of the present study were: (1) to provide a first approach to the spatial 99 coverage of filamentous mats in the benthic ecosystem around Rapa Nui, (2) to evaluate the extent 100 of the mesophotic coral reefs potentially impacted by these mats, and (3) to provide a preliminary 101 description of the taxonomic composition of these mats.

\section{Materials and methods}

Rapa Nui is a triangular-shaped island, delimited by the volcanoes Rano Kau in the southwest, 105 Terevaka in the north, and Poike in the east, with Hanga Roa, the main village, located on the western side (Fig. 1). Aiming to have a representative spatial and bathymetric ( $\sim 40$ to $350 \mathrm{~m}$ deep) characterization of the mesophotic habitats on the three sides of the island, a remotely operated vehicle (ROV), controlled from local fishing boats, was deployed in 56 mostly independent sites around the island. There were 18 deployments each in January 2018 and 2019, and 20 during November and December 2019 (Fig. 1). The ROV, model Commander MKII (Mariscope Meerestechnik, Kiel, Germany), was equipped with two laser pointers, $10 \mathrm{~cm}$ apart, and a frontpointing HD video camera (Panasonic SD 909), angled at $45^{\circ}$ and recording at 30 fps with a 
113 resolution of $1920 \times 1080$ pixels. The videos were analyzed at half their normal speed using GOM

114 Player 2.3.19 (GOM \& Company; https://www.gomlab.com/).

115 As mentioned in the Introduction, some of the results of these and previous ROV surveys have

116 been presented elsewhere (Easton et al., 2017; Easton et al., 2019; Hoeksema, Sellanes \& Easton,

117 2019; Mecho et al., 2019, for selected biotic components). For the present study, however, the

118 focus was to evaluate the spatial coverage of filamentous mats in the benthic ecosystem, and the

119 extent of mesophotic reefs potentially impacted by these mats, as well as their overall health

120 conditions. The presence and coverage of filamentous mats were assessed semi-quantitatively by

121 observing the seafloor in a stepwise manner as the ROV advanced over the ground along transects.

122 Bottom-time varied between 10 and 42 min (mean: 25 min) per transect. In general, a portion of

12310 to 20 min of video, considering mainly those segments in which the ROV was displaced at a

124 steady velocity and a suitable distance from the bottom, was selected and analyzed per site. For

125 each transect, we analyzed an area of at least $10 \mathrm{~m}^{2}$, corresponding to $\sim 15$ non-overlapping frames.

126 We exclusively analyzed those frames when the ROV was approximately $25 \mathrm{~cm}$ above the ground

127 or in front of the reefs. As calibrated with the ROV on land, at these distances the images covered

128 an area of $\sim 0.65 \mathrm{~m}^{2}$ (width $\sim 117 \mathrm{~cm} \times$ height $\sim 65 \mathrm{~cm}$ ).

129 According to the extent to which the bottom or the coral was covered by filamentous mats, the

130 transects were cataloged into four groups: (1) without patches of filamentous mats, (2) low

131 coverage (less than $50 \%$ coverage in at least five non-overlapping frames of the video of a

132 transect), (3) high coverage (50\% to $75 \%$ coverage in at least five frames of the video of a transect),

133 and (4) very high coverage (100\% coverage). Statistical comparisons of the mean depth between

134 the four categories of filamentous mat coverage were evaluated using the Kruskal-Wallis test. Post

135 hoc analyses were performed using pairwise comparisons with the Wilcoxon rank sum test and the 
$136 p$-value was adjusted using the Holm method (Holm, 1979). Before comparisons, normality and

137 homogeneity of variance were tested using the Shapiro-Wilk and Levene tests, respectively.

138 Statistical analyses were performed using RStudio (R Studio Team, 2020), specifically the "car"

139 package (Fox and Weisberg, 2019) and the "ggplot2" package for boxplots (Wickham, 2016).

140 We used the same ROV survey approximation to assess the extent of live coral coverage as a proxy

141 for coral health status. Three categories were considered: (1) a healthy reef with $>75 \%$ of the

142 corals alive, (2) some damage with $25 \%$ to $75 \%$ of the corals alive, and (3) mostly damaged with

$143<25 \%$ of the corals alive (mainly dead corals or fragments). Dead corals were easily identified by

144 their generally greenish or darker colors. Some were also covered by filaments.

145 To characterize the taxonomic composition of the filamentous mat assemblage, in May 2019, a

146 small benthic trawl with a horizontal aperture of $30 \mathrm{~cm}$ was deployed at a site off Hanga Roa,

147 where patches with $100 \%$ coverage were frequent. Mat samples were fixed using a $4 \%$ aqueous

148 solution of formaldehyde (ACS Reagent; Sigma-Aldrich, St. Louis, MO, USA). For morphological

149 characterization, filaments were observed using an Olympus IX71 inverted microscope equipped

150 with phase contrast and epifluorescence (Olympus Co., Tokyo, Japan). Micrographs were taken

151 using a camera ProgRes C3 (JENOPTIK AG, Jena, Germany), and measurements of cells (length

152 and width) were carried out using ProgRes ${ }^{\circledR}$ CapturePro (JENOPTIK AG) analytical software.

153 Monographic publications, floristic studies, and systematic articles were used for taxonomic

154 identification of the macroalgae composing the mats, at least to the genus level (Santelices, 1989;

155 Loiseaux-de Goër \& Noailles, 2008; Cormaci, Furnari \& Alongi, 2014; Ramirez et al., 2018).

156 Guides and systematic articles were used to identify the cyanobacteria inhabiting the mat samples

157 (Komarek \& Anagnostidis, 2007; Yu et al., 2015; Brocke et al., 2018; Zubia et al., 2019). The

158 identification of taxa was performed at the genus or species complex level. 
159 Sample collection was performed with permission Res. Ext $N^{\circ} 41 / 2016$ and $N^{\circ} 3314 / 2017$ from

160 SUBPESCA (National Fishing Authority of Chile) granted to the Universidad Católica del Norte.

161 This project was also presented to the local Consejo del Mar de Rapa Nui (Council of the Sea of

162 Rapa Nui), which permitted the capture of underwater footage and sampling around the island.

\section{Results}

The ROV transects around the island covered a depth range of 43 to $347 \mathrm{~m}$. This allowed us to visualize the spatial and bathymetric distribution of sites with different levels of filamentous mat coverage (Figs. 1, 2), and the distribution of mesophotic reefs and their health status around the Pocillopora spp. at shallower depths (<60 m), Leptoseris spp., and C. vaughani at depths between 70 and $117 \mathrm{~m}$, and sea-whips (Stichopathes spp.) between 127 and $327 \mathrm{~m}$ (Fig. 2). Other scleractinians were occasionally sighted deeper than $120 \mathrm{~m}$ (e.g., cup corals), but they were too small to identify using ROV images.

\section{Spatial distribution of filamentous mats and corals}

175 Filamentous mats were absent (category: without) from 34 of the studied sites around Rapa Nui, and low to very high coverage was observed at the remaining 22 sites, commonly on the western 177 side of the island (Fig. 1A) and in water shallower than $\sim 130 \mathrm{~m}$ (Fig. 1B). Statistical comparisons confirmed the significant differences between the depths of the mat-coverage categories (Kruskal-

179 Wallis, $\left.\mathrm{Chi}^{2}=12.9, \mathrm{df}=3, p=0.005\right)$, in particular between the categories without and very high 180 (Wilcoxon test, $p=0.023$; Fig. 1B). Other comparisons between categories were not significant 181 (Wilcoxon test, $p>0.05$ ). Indeed, high coverage was observed in the northwest corner (close to 
182 Hanga O'teo) at a depth of $123 \mathrm{~m}$, and high and very high coverages were observed mainly off

183 Hanga Roa (Fig. 1B) from 70 to $95 \mathrm{~m}$ deep.

184 Corals were observed in 50\% of the 56 transects (Fig. 3A), and Leptoseris was present in 11 of 185 them. Off Hanga Roa, the location where filamentous mats were most frequent, they were observed 186 covering the sediments (Fig. 2A, B), fringing fields of the zooxanthellate mushroom coral $C$. 187 vaughani (Fig. 2C, Fig. 3A; see also Hoeksema, Sellanes \& Easton, 2019), and close by dead 188 Leptoseris reefs ( $\sim 80 \mathrm{~m}$ deep), which were also overgrown by filamentous mats (Fig. 2D). Healthy 189 Leptoseris reefs were documented mainly off the northern and southeastern parts of the island 190 (e.g., near Anakena, La Perouse, and Vinapú) at depths of 68 to $82 \mathrm{~m}$ (Fig. 3B). Of the six locations 191 with the healthiest Leptoseris reefs, four of them had no filamentous mats, or a sporadic presence 192 of them, whereas at the three sites where the reefs were completely dead, filamentous mat coverage 193 was high or very high (see also supplementary material).

Taxonomic characterization of the filamentous mat assemblage

Morphological analyses of samples of mats collected off Hanga Roa indicated that mats are an assemblage of at least four taxa: one Chlorophyta (Cladophora sp.), one Ochrophyta (Ectocarpus sp.), and two Cyanobacteria (Lyngbya s.l. ([sensu lato] and Pseudoanabaena sp.) (Fig. 4) as follows: $\mathrm{cm}$ in total length. Basal part of the filaments fixed to the substrate by a primary rhizoid. Presence of unilateral branches inserted laterally or obliquely on the filament. Principal axis constituted by cylindrical cells measuring of $998.9 \pm 69.2 \mu \mathrm{m}$ in length and $223.3 \pm 9.5 \mu \mathrm{m}$ in 
204 diameter. Apical cells cylindrical, round ended with a diameter of $250.0 \pm 7.6 \mu \mathrm{m}$ and length of

$205701.8 \pm 76.0 \mu \mathrm{m}$. Zoosporangia were not observed.

206 Ectocarpus sp. (Fig. 4C, D): thallus of light brown to olive sparingly branched filament $0.1-0.5 \mathrm{~cm}$

207 in total length. Cells conform to uniseriate filaments ending in a rounded apical cell. Cells barrel-

208 shaped, $50.0 \pm 7.3 \mu \mathrm{m}$ in length, and $14.1 \pm 3.4 \mu \mathrm{m}$ in diameter. Plurilocular sporangia were

209 present, elongated with cylindroconical form, 80-130 $\mu \mathrm{m}$ in length and 20-30 $\mu \mathrm{m}$ in diameter.

210 Lyngbya s.1. (Fig. 4E, F): thallus caespitose, brownish-red, filaments slightly curved, sheet

211 colorless, lamellated with apices not attenuated at the end. Trichome not constricted at the cross-

212 wall, cylindrical cells very short $3.5 \pm 0.3 \mu \mathrm{m}$ in length and $7.1 \pm 0.1 \mu \mathrm{m}$ in diameter, sheath $1.6 \pm$

$2130.3 \mu \mathrm{m}$, end cells rotund, calyptra absent. Pseudoanabaena sp. (Fig. 4G, H): trichomes solitary or

214 crowded in clusters, straight or almost straight, pale blue-green. Cells barrel-shaped, $2.8 \pm 0.8 \mu \mathrm{m}$

215 in length and $1.2 \pm 0.1 \mu \mathrm{m}$ in diameter, intensely constricted at cross walls, no heterocysts or 216 sheath, end cells round.

\section{Discussion}

219 Although we have provided only a preliminary taxonomic characterization of the filamentous mats covering sandy areas and dead mesophotic reefs off Rapa Nui, our findings indicate that these mats are composed of at least two cyanobacteria. We are aware of, and recognize the limitations associated with our approach to identifying mat taxa, based only on morphology. As indicated by Komárek (2016), Lyngbya, Okeania, and Moorea cannot be distinguished from each other using light microscopy. Thus, we refer to Lyngbya s.l. ([sensu lato] and suggest that genetic analysis is needed to clarify this classification. Cyanobacteria-dominated microbial mats are known to be 
227 These events have been associated with natural processes (e.g., variation in irradiance), but mostly

228 with anthropogenic disturbances that increase nutrient concentrations in the marine environment

229 (Ford et al., 2017). The highest coverage of mats was observed mainly off Hanga Roa village,

230 which has the highest concentration of the island's human population $(7,750$ inhabitants;

231 www.ine.cl) and where most tourists engage in recreational activities. Figueroa \& Rotarou (2016)

232 reported $\sim 20,000$ visitors per year in the late 1990s, whereas $\sim 150,000$ were reported during 2019

233 (www.sernatur.cl), representing an approximately eight-fold increase over the last two decades.

234 Factors such as overtourism, the absence of a wastewater collection and treatment system (most

235 of the residences have cesspools and a minor proportion have septic tanks), and the unlined landfill

236 (Rosa, 2013) potentially pose a great threat to the marine environment off Hanga Roa village,

237 owing to the potential input of organic matter, nutrients, and contaminants. Pollutants can reach

238 the sea by runoff or percolation to aquifers that eventually discharge into the sea. On Rapa Nui,

239 submarine groundwater discharges are ubiquitous in intertidal environments around the island

240 (Brosnan, Becker \& Lipo, 2018), and could hypothetically also seep through deeper sediments

241 (Montgomery \& Associates, 2011), potentially conducting nutrients of anthropogenic origin

242 directly to mesophotic habitats. Indeed, very low salinities (4.7-16.8 psu) have been measured in

243 the overlying water of unperturbed sediment cores obtained off Hanga Roa where filamentous

244 mats proliferate, further suggesting percolation of pollutants to aquifers in the area (P. Muñoz,

245 unpublished data). A similar situation has been observed at the western flank of Hawai'i Island,

246 where freshwater from onshore aquifers can flow through permeable fractured basalts, mix with

247 seawater to form freshened groundwater, and seep into offshore (mesophotic) benthic areas (Attias

248 et al., 2020). Furthermore, the observation of low salinity bottom water is concomitant with

249 relatively high $\mathrm{NO}_{3}{ }^{-}$concentrations $(1.87$ and $3.03 \mu \mathrm{M})$, compared to two other sites where nitrate 
250 concentrations were undetectable in overlying waters with normal salinities ( $\sim 35 \mathrm{psu})$ (P. Muñoz,

251 unpublished data). Therefore, it is feasible that the benthic fluxes and submarine groundwater

252 discharges could channel nutrients to mesophotic depths, enhancing algal and cyanobacterial

253 growth, to the detriment of corals. A similar situation, albeit caused by groundwater nutrients

254 derived from bird guano, was observed in the coral reefs of Heron Island (Great Barrier Reef,

255 Australia; McMahon \& Santos, 2017). In addition to the potential impacts of pollutants, the

256 permanent coastal erosion around Rapa Nui and terrestrial runoff during rainy seasons (May to

257 October) could also increase nutrient inputs to the coastal environments, including ammonia,

258 nitrate, and silicate, which are known to have negative consequences for corals (D'Angelo \&

259 Wiedenmann, 2014). Furthermore, the volcanic origin of Rapa Nui, together with enhanced

260 erosion could also increase the iron concentration in the marine ecosystem. Iron from shipwrecks

261 has been found to directly drive cyanobacteria expansion in iron-limited reefs in the Pacific (Kelly

262 et al., 2012; Mangubhai \& Obura, 2019). Increased iron added to a decrease in the N:P ratio could

263 even further stimulate the proliferation of cyanobacteria (Ford et al., 2018).

264 Regarding mesophotic reefs, two species of the genus Leptoseris have been reported for Rapa Nui, 265 L. scabra and L. solida, both collected in 1999 off Hanga Roa at depths of $43 \mathrm{~m}$ and 80 to $100 \mathrm{~m}$,

266 respectively (Glynn et al., 2003). Given the depth of our observations as well as the plate-like

267 structure of the colonies, as indicated by Glynn et al. (2003), the damaged reef off Hanga Roa

268 village was probably composed mainly of L. solida. A piece of evidence, also obtained in

269 November 1999 during the first ROV survey ever done off Hanga Roa at $\sim 80 \mathrm{~m}$ deep, suggests

270 that the same Leptoseris reef that is currently dead was healthy 20 years ago (Fig. 2D; Gorny \&

271 Retamal, 2000). In the present study, live Leptoseris reefs were documented mainly off the

272 northern and southeastern sides of the island (e.g., Anakena, La Perouse, and Vinapú). 
273 Despite the circumstantial indication of the health status of the mesophotic reefs off Hanga Roa a

274 few decades ago, the ecological impacts on the biodiversity and ecosystem functioning associated

275 with anthropogenic causes are still unknown and need further investigation in the short term.

276 Further research should address a more detailed taxonomic characterization of these mats, for

277 example, through molecular techniques; assessment of the seasonal, spatial, and structural patterns

278 of the assemblage; their eventual role in reef deterioration; recognition of eutrophication

279 mechanisms; and long-term monitoring of dissolved organic matter and nutrient dynamics. These

280 studies are encouraged to inform the implementation of effective and integrated land-sea

281 management actions, including a wastewater treatment system. This information should also be

282 key to inform the implementation of management strategies of the recently created Marine

283 Protected Area of Multiple Uses (MPA-MU) of Rapa Nui, currently the largest in Latin America.

284 This protected area encompasses $\sim 579,000 \mathrm{~km}^{2}$ (Paredes et al., 2019) and aims to protect this

285 unique world biodiversity heritage site. In addition, this study will also serve as a baseline for

286 future studies of changes in the mesophotic ecosystem off Rapa Nui after closure of the island to

287 tourism, from March 2020 to date, due to the COVID-19 pandemic.

\section{Conclusions}

290 Based on opportunistic video observations, we provide the first report of filamentous mats 291 covering sandy areas and dead mesophotic reefs (Leptoseris spp.) off Rapa Nui. A preliminary 292 morphological analysis of mat samples suggested that the assemblage is constituted by at least four 293 filamentous taxa, including two cyanobacteria (Lyngbya s.l. and Pseudoanabaena sp.), a brown 294 alga (Ectocarpus sp.), and a green alga (Cladophora sp.). Whereas a highly damaged, even 295 completely dead, Leptoseris reef was observed in the waters off the main village on the western 
296 side of the island, reefs in much healthier conditions were observed off the less populated northern

297 and southeastern parts of the island (e.g., Anakena, La Perouse, and Vinapú). Circumstantial

298 evidence indicates that the Leptoseris reef off Hanga Roa was alive $\sim 20$ years ago. Our preliminary

299 evidence suggests a link between ongoing eutrophication associated with human population

300 expansion and deficient management of wastewater and urban runoff on the western side of the

301 island, the proliferation of filamentous mats, and consequent damage to mesophotic Leptoseris 302 reefs.

303

304

Acknowledgments

305

306

307

308

309

310

311

312

313

314

315

316

317

318

We thank Poky Tane Haoa, Ricardo Hito, and Enrique Hey from the Rapa Nui community. We also thank Erin Easton and Ariadna Mecho for their collaboration during fieldwork, and Maria Valladares and Valentina Hevia for helping with the collection of the samples. Our thanks go to Bert Hoeksema for his valuable comments on a very early version of this manuscript, as well as to Amanda Ford, Marc Slattery, and an anonymous reviewer.

\section{References}

Albert S, Dunbabin M, Skinner M, Moore B. 2012. Benthic shift in a Solomon Islands' lagoon: corals to cyanobacteria. Proceedings of the 12th International Coral Reef Symposium, Cairns, Australia.

Andradi-Brown D, Laverick J, Bejarano I, Bridge T, Colin PL, Eyal G, Jones R, Kahng SE, Reed

J, Smith TB, Spalding H, Well E, Wood E. 2016. Threats to mesophotic coral ecosystems and 
319 management options. In: Baker EK, Puglise, KA and Harris, PT, eds. Mesophotic coral 320 ecosystems - A lifeboat for coral reefs? The United Nations Environment Programme and GRID-

321 Arendal, Nairobi and Arendal, pp. 98

322

323 Attias E, Thomas D, Sherman D, Ismail K, Constable S. 2020. Marine electrical imaging reveals 324 novel freshwater transport mechanism in Hawai'i. Science Advances 6(48): eabd4866. DOI: $32510.1126 /$ sciadv.abd4866

327 Baker E, Puglise KA, Colin PL, Harris PT, Kahng SE, Rooney JJ, Sherman C, Slattery M, Spalding 328 HL. 2016. What are mesophotic coral ecosystems? In: Baker EK, Puglise KA and Harris PT, eds. Mesophotic coral ecosystems-A lifeboat for coral reefs? The United Nations Environment 330 Programme and GRID-Arendal, Nairobi and Arendal, pp. 98

Bakker D, van Duyl F, Bak R, Nugues MM, Nieuwland G, Meesters E. 2017. 40 Years of benthic community change on the Caribbean reefs of Curacao and Bonaire: the rise of slimy cyanobacterial mats. Coral Reefs D अ 10.1007/s00338-016-1534-9

Barile PJ. 2004. Evidence of anthropogenic nitrogen enrichment of the littoral waters of East Central Florida. Journal of Coastal research 20:137 -1245

Birrel C, McCook L, Willis B, Diaz-Pulido G. 2008. Effects of benthic algae on the replenishment of corals and the implications for the resilience of coral reefs. Oceanography and Marine Biology: An Annual Review 46:25-63 
343 Brocke HJ, Polerecky L, de Beer D, Weber M, Claudet J, Nugues MM. 2015. Organic Matter

344 Degradation Drives Benthic Cyanobacterial Mat Abundance on Caribbean Coral Reefs. PLoS One 345 10(5): e0125445. doi:10.1371/journal.pone.0125445

346

347 Brocke HJ, Piltz B, Herz N, Abed RMM, Palinska KA, John U, Haan JD, de Beer D, Nugues MM. 348 2018. Nitrogen fixation and diversity of benthic cyanobacterial mats on coral reefs in Curaçao. 349 Coral Reefs 37(3): 861-874

350

351

352

353 $\underline{1870-7}$

354

355

356

Charpy L, Casareto BE, Langlade MJ, Suzuki Y. 2012. Cyanobacteria in coral reef ecosystems: a review. Journal of Marine Sciences, Article ID 259571 https://doi.org/10.1155/2012/259571

357

Cissell EC, Manning JC, McCoy SJ. 2019. Consumption of benthic cyanobacterial mats on a 359 Caribbean coral reef. Scientific Reports 9:12693. https://doi.org/10.1038/s41598-019-49126-9

Cormaci M, Furnari G, Alongi G. 2014. Flora marina bentónica del Mediterráneo: Chlorophyta. 
364 D'Angelo, C., and Wiedenman, J. 2014. Impacts of nutrient enrichment on coral reefs: new

365 perspectives and implications for coastal management and reef survival. Current Opinion in 366 Environmental Sustainability 7:82-93.

367

368

Easton EE, Sellanes J, Gaymer CF, Morales N, Gorny M, Berkenpass E. 2017. Diversity of deepsea fishes of the Easter Island Ecoregion. Deep Sea Res Part II 137:78-88. https://doi.org/10.1016/j.dsr2.2016.12.006

Easton EE, Gorny, M, Mecho A, Sellanes J, Gaymer CF, Slapding HL, Aburto J. 2019. Chile and Ecosystems. Springer International Publishing, pp 477-490. https://doi.org/10.1007/978-3-319$\underline{92735-0}$

Fabricius K. 2005. Effects of terrestrial runoff on the ecology of corals and coral reefs: review and synthesis. Marine Pollution Bulletin 50:125-146

Fernandez M, Pappalardo P, Rodriguez Ruiz MC, Castilla JC. 2014. Synthesis of the state of knowledge about species richness of macroalgae, macroinvertebrates and fishes in coastal and oceanic waters of Easter and Salas y Gomez islands. Latin American Journal of Aquatic Research 42(4):760-802

Figueroa E, Rotarou ES. 2016. Sustainable Development or Eco-Collapse: Lessons for Tourism and Development from Easter Island. Sustainability 8:1093. https://doi.org/10.3390/su8111093 
388 Ford A, Van Hoytema N, Moore B, Pandiha L, Wild C, Ferse S. 2017. High sedimentary oxygen 389 consumption indicates that sewage input from small islands drives benthic community shifts on 390 overfished reefs. Environmental Conservation 44(4):405-414. 391 https://doi.org/10.1017/S0376892917000054

393 Ford AK, Bejarano S, Nugues MM, Visser PM, Albert S, Ferse SCA. 2018. Reefs under siege-the 394 rise, putative drivers, and consequences of benthic cyanobacterial mats. Frontiers in Marine 395 Science 5:18. https://doi.org/10.3389/fmars.2018.00018

396

397 Ford AK, Visser PM, van Herk MJ, Jongepier E, Bonito V. 2021. First insights into the impacts of 398 benthic cyanobacterial mats on fish herbivory functions on a nearshore coral reef. Scientific 399 Reports 11:7147. https://doi.org/10.1038/s41598-021-84016-z

400

401 Fox J, Weisberg S. 2019. An R Companion to Applied Regression. Sage, Thousand Oaks CA, 3rd 402 edition. URL http://z.umn.edu/carbook.

403

404 Glynn PW, Wellington GM, Riegl B, Olson DB, Borneman E, Wieters EA. 2007. Diversity and 405 biogeography of the scleractinian coral fauna of Easter Island (Rapa Nui). Pacific Science 61:67406 90. https://doi.org/10.1353/psc.2007.0005 
408 Gorny M, Retamal M. 2000. Estudio sobre la biodiversidad del megabentos de Isla de Pascua y 409 Salas y Gómez mediante video subacuático. Libro de Resúmenes. Taller sobre los resultados del 410 Crucero Cimar-Fiordo 5. Valparaíso: 119-121

411

412 Hidalgo-Ruz V, Luna-Jorquera G, Eriksen M, Frick H, Miranda-Urbina D, Porflitt-Toro M, 413 Rivadeneira M, Robertson CJR, Scofield RP, Serratosa J, Suazo CG, Thiel M. 2021. Factors (type, 414 colour, density, and shape) determining the removal of marine plastic debris by seabirds from the 415 South Pacific Ocean: Is there a pattern? Aquatic Conservation: Marine and Freshwater Ecosystem $416 \quad 31: 389-407$

418 Hoeksema BW, Sellanes J, Easton EE. 2019. A high-latitude, mesophotic Cycloseris field at $85 \mathrm{~m}$ 419 depth off Rapa Nui (Easter Island). Bulletin of Marine Science 95: https://doi.org/10.5343/bms.2018.0053

421

422 Holm S. 1979. A simple sequentially rejective multiple test procedure. Scandinavian Journal of 423 Statistics 6: 65-70.

Kelly LW, Barott KL, Dinsdale E, Friedlander AM, Nosrat B, Obura D, Sala E, Sandin SA, Smith 426 JE, Vermeij MJA, Williams GJ, Willner D, Rohwer F. 2012. Black reefs: iron-induced phase shifts on coral reefs. The ISME Journal 6: 638-649 https://doi.org/10.1038/ismej.2011.114

428

429 Komárek, J. 2016. A polyphasic approach for the taxonomy of cyanobacteria: principles and 430 applications. European Journal of Phycology 51:346-353. 
432 Komarek J, Anagnostidis K. 2007. Süßwasserflora von Mitteleuropa, Bd. 19/2: Cyanoprokaryota.

Bd. 2 / Part 2: Oscillatoriales. Springer Spektrum

434

435

Koop K, Booth D, Broadbent A, Drodie J, Bucher D, Capone D, Coll J, Dennison W, Erdmann 436

M, Harrison P, Hoegh-Guldberg O, Hutchings P, Jones GB, Larkum AWD, O’Neil J, Steven A, 437 Tentori E, Ward S, Williamson J, Yellowless D. 2001. ENCORE: The effect of nutrient enrichment 438 on coral reefs. Synthesis of results and conclusions. Marine Pollution Bulletin 42:91-120

439

440

Laurent D, Kerbrat AS, Darius HT, Girard E, Golubic S, Benoit E, Sauviat MP, Chinain M, Molgo 441

J, Pauillac S. 2008. Are cyanobacteria involved in Ciguatera Fish Poisoning-like outbreaks in New 442 Caledonia? Harmful Algae 7:827-838

443

444

Loiseaux-de Goër S, Noailles MC. 2008. Algues de Roscoff. Editions de la Station Biologique de 445 Roscoff

446

447

Mecho A, Easton EE, Sellanes J, Gorny M. Mah C. 2019. Unexplored diversity of the mesophotic 448 echinoderm fauna of the Easter Island Ecoregion. Marine Biology .org/10.1007/s00227-o19$3537-\mathrm{x}$

450

451

Mieth A, Bork H-R. 2005. History, origin and extent of soil erosion on Easter Island (Rapa Nui).

452

Catena 63:244-260

453 
454 Montgomery EL \& Associates INC. 2011. Condiciones hidrogeológicas Isla de Pascua, Chile.

455 Dirección general de aguas. Pp. 48

456

457 McMahon A, Santos IR. 2017. Nitrogen enrichment and speciation in a coral reef lagoon driven

458 by groundwater inputs of bird guano. Journal of Geophysical Researcj Oceans 122: 7218-7236.

459 doi:10.1002/2017JC012929.

460

461 Mangubhai S, Obura D.O. 2018. Silent killer: Black reefs in the Phoenix Islands Protected Area.

462 Pacific Conservation Biology 25 (2):213-214

463

464 Myers J, Richardson L. 2009. Adaptation of cyanobacteria to the sulfide-rich microenvironment 465 of black band disease of coral. FEMS Microbiology Ecology 67:242-251

466

467 Nagle DG, Paul VJ. 1999. Production of secondary metabolites by filamentous tropical marine 468 cyanobacteria: ecological functions of the compounds. Journal of Phycology 35:1412-1421

469

470

Paerl HW, Otten TG. 2013. Harmful Cyanobacterial Blooms: Causes, Consequences and Controls.

471 Microbial Ecology 65:995-1010

472

473 Paerl H, Paul V. 2012. Climate change: Links to global expansion of harmful cyanobacteria. Water 474 Research 46(5):1349-1363

475 
476 Paredes F, Flores D, Figueroa A, Gaymer C, Aburto J. 2019. Science, capacity building and 477 conservation knowledge: The empowerment of the local community for marine conservation in 478 Rapa Nui. Aquatic Conservation: Marine and Freshwater Ecosystem 130-137 479 Doi.org/10.1002/aqc.3114

480

481

482

Paul VJ. 2008. Global warming and cyanobacterial harmful algal blooms. In: Hudnell HK, Ed. Cyanobacterial Harmful Algal Blooms: State of the Science and Research Needs. Advances in 483 Experimental Medicine and Biology, Springer 619:239-257

484

485

Ramirez ME, Bulboa C, Contreras L, Mora AM. 2018. Algas marinas de Quintay. RiL Editores

486

487

488

Randall JE, Cea A. 2010. Shore fishes of Easter Island. University of Hawai'i

Press, Honolulu.

489

490

Rocha LA, Pinheiro HT, Shepherd B, Papastamatiou YP, Luiz OJ, Pyle RL, Bongaerts P. 2018.

491

Mesophotic coral ecosystems are threatened and ecologically distinct from shallow water reefs.

492

Science 361:281-284. https://doi.org/10.1126/science.aaq1614

493

494

Rodrigo C, Díaz J, González-Fernández A. 2014. Origin of the Easter Submarine Alignment:

495 morphology and structural lineaments. Latin American Journal of Aquatic Research 42(4):857496 870 http://dx.doi.org/10.3856/vol42-issue4-fulltext-12

497 
498 Rosa K. 2013. A hydrologic overview and discussion of sources of groundwater pollution on Rapa

499 Nui. Rapa Nui Journal 27(2): 51-59

500

501 R Studio Team. 2020. RStudio: Integrated Development for R. Boston, MA: RStudio, PBC.

502

503 Santelices B. 1989. Algas Marinas de Chile. Ediciones Universidad Católica de Chile

504

505 Slattery M, Lesser MP. 2021. Gorgonians Are Foundation Species on Sponge-Dominated

506 Mesophotic Coral Reefs in the Caribbean. Frontiers in Marine Science 8: 654268.

507 https://doi.org/10.3389/fmars.2021.654268

508

509 Stal LJ. 2000. Cyanobacterial mats and stromatolites. In: Whitton PA, Potts M, eds. The ecology 510 of cyanobacteria: their diversity in time and space. Kluwe Academic, Dordrecht, pp 61-120

511

512 Wickham H. 2016. ggplot2: Elegant Graphics for Data Analysis. Springer-Verlag New York 513

514 Yu G, Zhu M, Chen Y, Pan Q, Chai W, Li R. 2015. Polyphasic characterization of four species of 515 Pseudanabaena (Oscillatoriales, Cyanobacteria) from China and insights into polyphyletic 516 divergence within the Pseudanabaena genus. Phytotaxa 192(1):1-12

517

518 Zubia M, Vieira C, Palinska KA, Roué M, Gaertner J-C, Zloch I, Grellier M, Golubic S. 2019.

519 Benthic cyanobacteria on coral reefs of Moorea Island (French Polynesia): diversity response to 520 habitat quality. Hydrobiologia 843(1):61-78 
522 Zylich K, Harper S, Licandeo R, Vega R, Zeller D, Pauly D. 2014. Fishing in Easter Island, a 523 recent history (1950-2010). Latin American Journal of Aquatic Research 42(4):845-856

524

525 Compliance with ethical standards

526 Conflict of interest: The authors declare that they have no competing interests.

527

528 Electronic Supplementary Material (ESM): Video footage of the cyanobacteria-like mats, live 529 Cycloseris sp. fields, and dead Leptoseris spp. reefs.

530 


\section{Figure 1}

Map of Rapa Nui showing the main features of the island, the sites surveyed in the present study, and the extent of coverage of filamentous mats at these sites.

(A) Abundance of filamentous mats in the benthic ecosystems at the survey sites. (B) Depth range of the remotely operated vehicle stations for each category of filamentous mat coverage used in this study. Green: no mats observed, yellow: low coverage, orange: high coverage, and red: very high coverage. The box plots show the mean (red diamonds), median (horizontal black line), and lower and upper quartiles; the whiskers indicate the depth range for each category. The letters $(a, b)$ indicate homogenous groups identified using the Wilcoxon post hoc test.
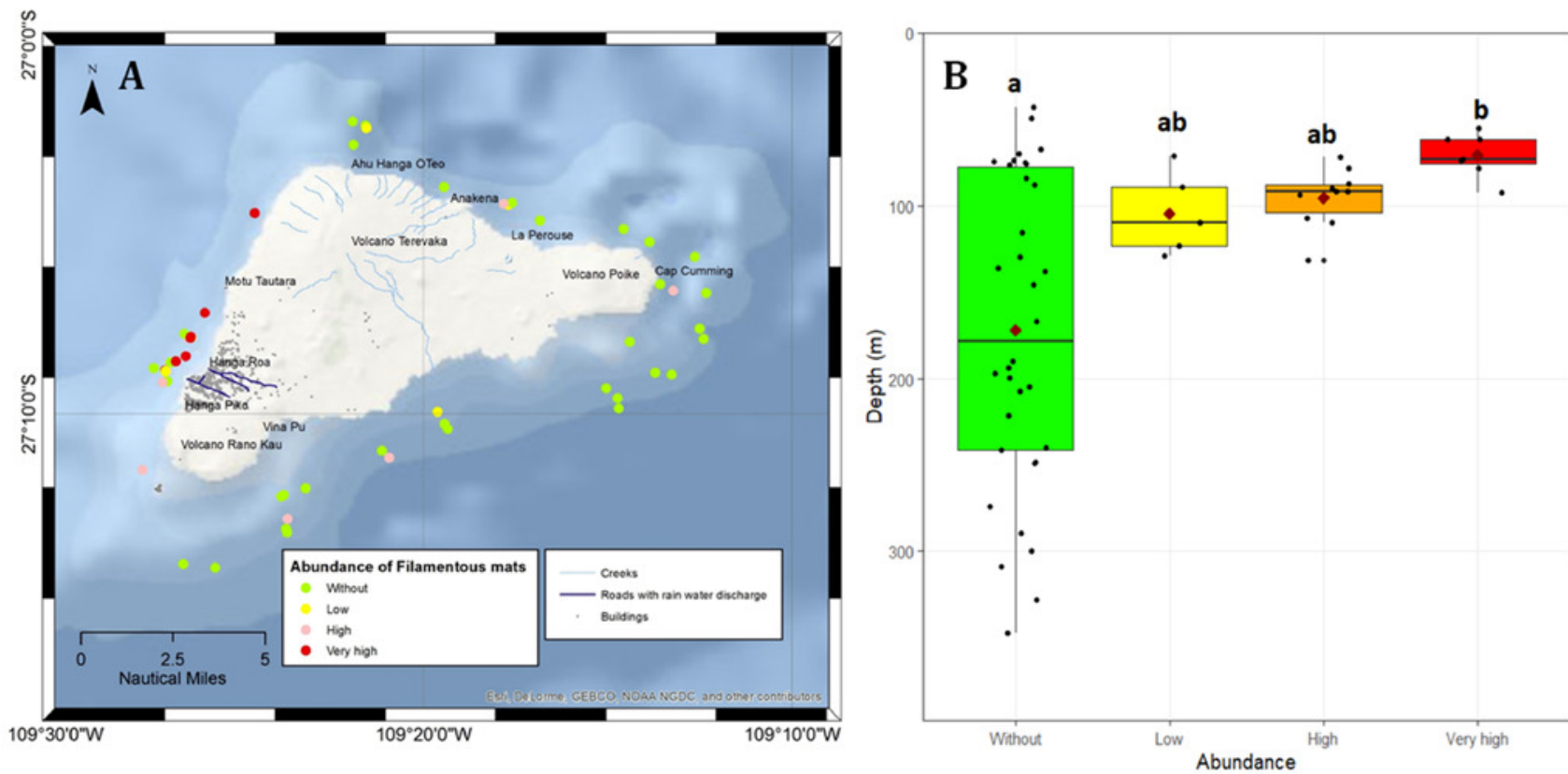

Abundance

Without

Low

High

Very high 


\section{Figure 2}

Remotely operated vehicle (ROV) images of the filamentous mats and mesophotic reefs off Rapa Nui.

(A) Field of filamentous mats at $\sim 80 \mathrm{~m}$ deep off Hanga Roa, Rapa Nui. (B) Close up view of the filaments. (C) Filaments among Cycloseris vaughani individuals. (D) Dead Leptoseris reef $\sim 80 \mathrm{~m}$ deep overgrown by filaments. (E) Healthy Leptoseris reef off Anakena $\sim 80 \mathrm{~m}$ deep. (F) Healthy Leptoseris reef off Hanga Roa filmed during prospective ROV surveys during the "CIMAR-5 Islas" cruise conducted in 1999. Scale bars: $10 \mathrm{~cm}(A, B, C)$ and $25 \mathrm{~cm}(\mathrm{D}, \mathrm{E}, \mathrm{F})$. Images: Matthias Gorny, OCEANA. 


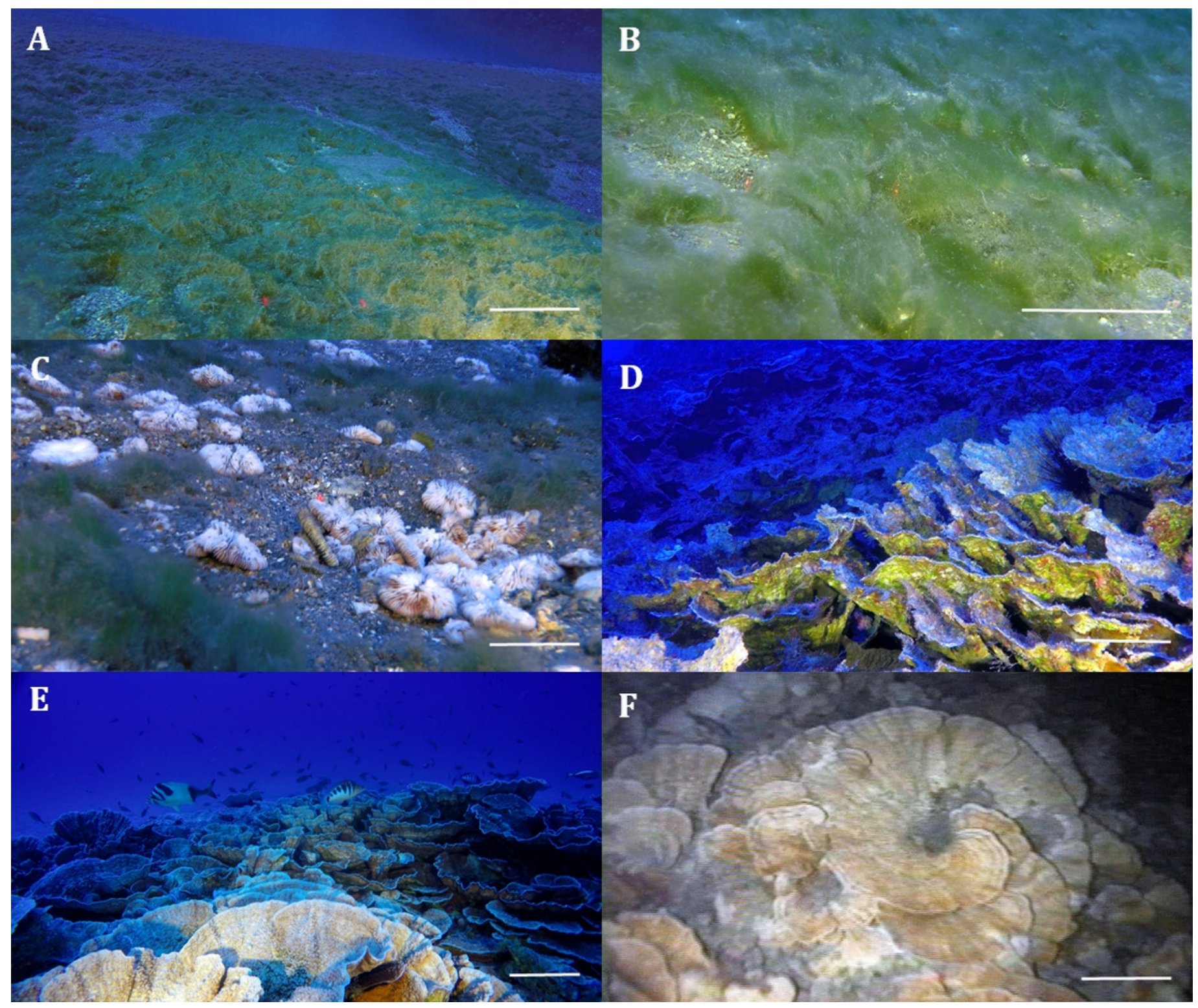




\section{Figure 3}

Transects surveyed off Rapa Nui in the present study showing sites with mesophotic corals.

(A) Map showing the main mesophotic coral taxa at each site. (B) Health status of Leptoseris reefs indicated by color: green $=$ healthy (no noticeable impact), yellow $=$ some damage $(25 \%-75 \%$ of corals damaged), and red $=$ destroyed (only dead corals or fragments observed).
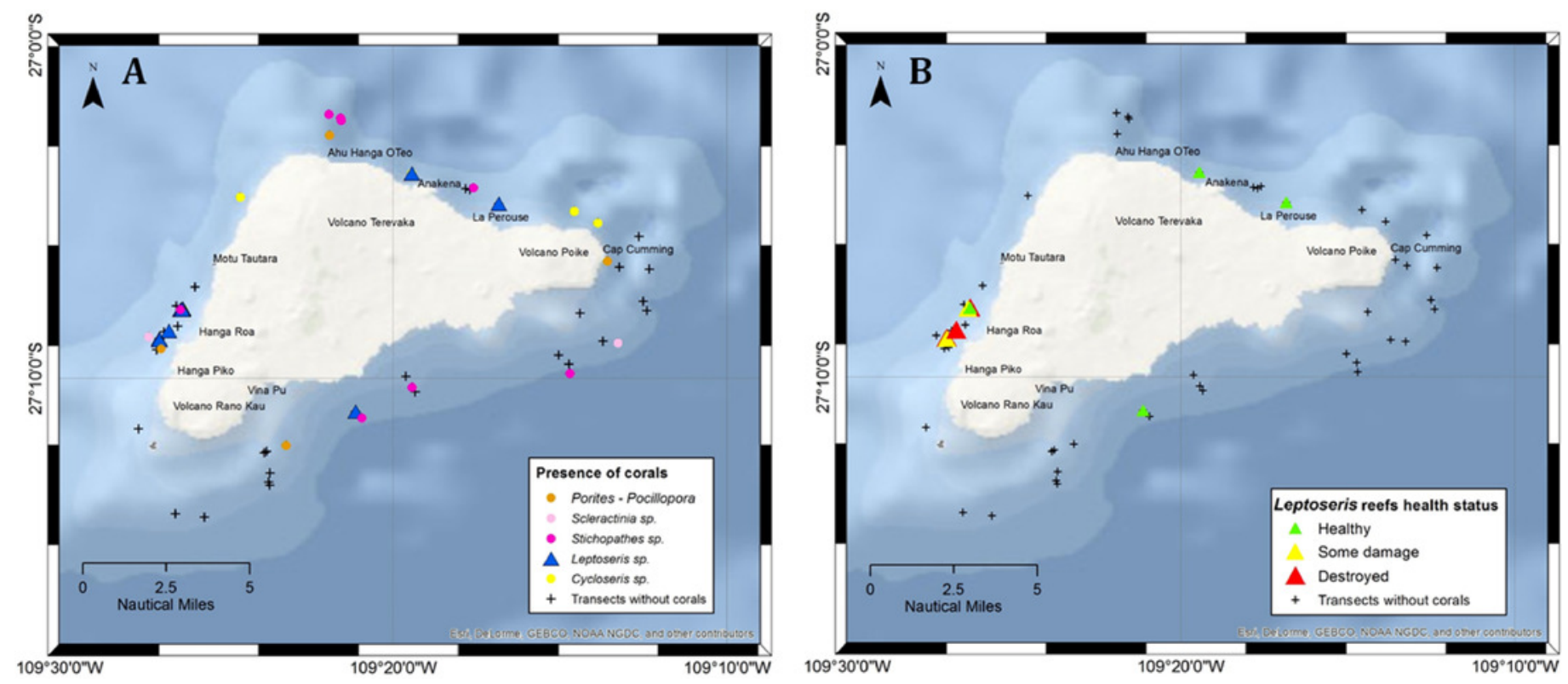
Figure 4

Micrographs of four filamentous taxa in samples from mats collected off Hanga Roa, Rapa Nui at mesophotic depths. A-E and $G$ were photographed using phase-contrast and $\mathrm{F}$ and $\mathrm{H}$ using epifluorescence techniques.

A, B) Cladophora sp. (C, D) Ectocarpus sp. (E, F) Lyngbya s.I. (G, H) Pseudoanabaena sp.

Scale bars represent A: $500 \mu \mathrm{m}, \mathrm{B}: 200 \mu \mathrm{m}, \mathrm{C}: 100 \mu \mathrm{m}, \mathrm{D}: 30 \mu \mathrm{m}, \mathrm{E}$ and F: $20 \mu \mathrm{m}$, and G and $\mathrm{H}: 30 \mu \mathrm{m}$. 


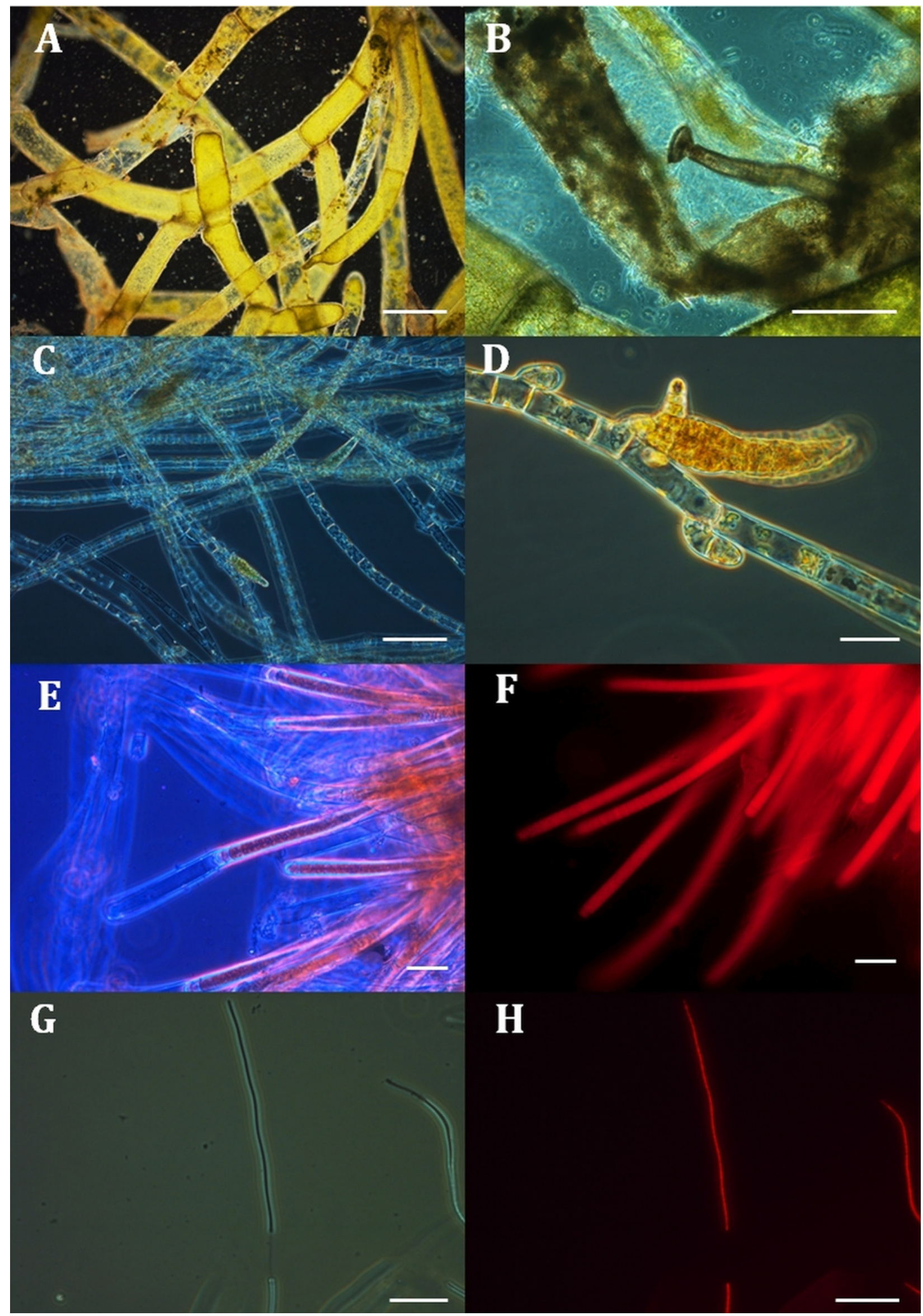

